\title{
Presynaptic Depression at a Calyx Synapse: The Small Contribution of Metabotropic Glutamate Receptors
}

\author{
Henrique von Gersdorff, Ralf Schneggenburger, Sibylle Weis, and Erwin Neher \\ Department of Membrane Biophysics, Max Planck Institute for Biophysical Chemistry, D-37077 Göttingen, Germany
}

Synaptic depression of evoked EPSCs was quantified with stimulation frequencies ranging from 0.2 to $100 \mathrm{~Hz}$ at the single CNS synapse formed by the calyx of Held in the rat brainstem. Half-maximal depression occurred at $\approx 1 \mathrm{~Hz}$, with 10 and 100 $\mathrm{Hz}$ stimulation frequencies reducing EPSC amplitudes to $\approx 30 \%$ and $\approx 10 \%$ of their initial magnitude, respectively. The time constant of recovery from depression elicited by $10 \mathrm{~Hz}$ afferent fiber stimulation was $4.2 \mathrm{sec}$. AMPA and NMDA receptor-mediated EPSCs depressed in parallel at 1-5 Hz stimulation frequencies, suggesting that depression was induced by presynaptic mechanism(s) that reduced glutamate release. To determine the contribution of autoreceptors to depression, we studied the inhibitory effects of the metabotropic glutamate receptor (mGluR) agonists (1S, 3S)-ACPD and L-AP4 and found them to be reversed in a dose-dependent manner by (RS)- $\alpha$ cyclopropyl-4-phosphonophenylglycine (CPPG), a novel and potent competitive antagonist of mGluRs. At $300 \mu \mathrm{M}, \mathrm{CPPG}$ completely reversed the effects of L-AP4 and (1S, 3S)-ACPD, but reduced $5-10 \mathrm{~Hz}$ elicited depression by only $\approx 6 \%$. CPPGsensitive mGluRs, presumably activated by glutamate spillover during physiological synaptic transmission, thus contribute on the order of only $10 \%$ to short-term synaptic depression. We therefore suggest that the main mechanism contributing to the robust depression elicited by $5-10 \mathrm{~Hz}$ afferent fiber stimulation of the calyx of Held synapse is synaptic vesicle pool depletion.

Key words: EPSCs; NMDA; AMPA; competitive antagonist; synaptic transmission; auditory brainstem slices; secretion; short-term plasticity
Use-dependent synaptic depression is a ubiquitous phenomenon observed in a wide variety of synapses from invertebrates (Kusano and Landau, 1975; Charlton et al., 1982; Atwood et al., 1994) to mammals (Debanne et al., 1996; Rosenmund and Stevens, 1996). In the mammalian neocortex, for example, synaptic depression is the predominant form of short-term synaptic plasticity observed between pyramidal cell pairs that have a high release probability (Thomson et al., 1993; Abbott et al., 1997; Tsodyks and Markram, 1997). Understanding the properties and underlying mechanisms that generate synaptic depression therefore is vital for an understanding of how neural networks operate in the brain. Multiple cellular mechanisms, perhaps acting simultaneously, may be responsible for the generation of synaptic depression. Some proposed mechanisms are autoreceptor activation (e.g., metabotropic glutamate receptor, mGluR; Forsythe and Clements, 1990; Baskys and Malenka, 1991; Nakanishi, 1994; Takahashi et al., 1996), presynaptic calcium current inactivation (Wu and Saggau, 1997), depletion of the readily releasable pool of synaptic vesicles at active zones (Thies, 1965; Liu and Tsien, 1995; Stevens and Tsujimoto, 1995), postsynaptic receptor desensitization (Magleby and Pallotta, 1981; Trussell et al., 1993; Otis et al., 1996), and adaptation of the calcium sensor for exocytosis (Hsu et al., 1996). To study and quantify how much each of these different processes contributes to depression, a CNS

Received June 26, 1997; revised Aug. 8, 1997; accepted Aug. 12, 1997.

This work was supported by the Deutsche Forschungsgemeinschaft (SFB406) and by Alexander von Humboldt and Human Frontier Science Program fellowships to H.v.G. We thank Drs. J. G. G. Borst and I. D. Forsythe for advice on the MNTB brainstem slice preparation.

Correspondence should be addressed to Dr. Henrique von Gersdorff, MaxPlanck-Institut für biophysikalische Chemie, Abteilung Membranbiophysik, Am Fassberg D-37077, Göttingen, Germany.

Copyright (C) 1997 Society for Neuroscience $\quad 0270-6474 / 97 / 178137-10 \$ 05.00 / 0$ synapse preparation that expresses robust synaptic depression is necessary.

A model CNS synapse is the calyx of Held, where a single large calyciform terminal synapses onto each principal neuron of the medial nucleus of the trapezoid body (MNTB) in the mammalian brainstem (Forsythe and Barnes-Davies, 1993; Borst et al., 1995). This axo-somatic glutamatergic synapse is involved in computing sound localization, and the calyx structure, with its multiple active zones, ensures fast, reliable synaptic transmission. We have characterized short-term plasticity (Magleby, 1987) at this synapse by recording EPSCs evoked by trains of presynaptic action potentials delivered at various frequencies $(0.2-100 \mathrm{~Hz})$. We show that AMPA and NMDA receptor-mediated EPSCs depress in a parallel manner for $1-5 \mathrm{~Hz}$ stimulation frequencies. This suggests that glutamate release is reduced during stimulation trains at these frequencies and that depression is attributable to presynaptic mechanism(s) and is not a consequence of postsynaptic receptor desensitization.

Recently, evidence was reported that use-dependent spillover of glutamate from the synaptic cleft (Asztely et al., 1997) can activate presynaptic mGluRs (Scanziani et al., 1997) and thus lead to depression. By using a potent antagonist of group II and III mGluRs, $(R S)$ - $\alpha$-cyclopropyl-4-phosphonophenylglycine (CPPG) (Jane et al., 1996), we have investigated whether the activation of presynaptic mGluRs sensitive to L-AP4 and ACPD is involved in producing short-term synaptic depression at the calyx of Held. We conclude that they contribute on the order of only $10 \%$ to the overall depression elicited by $5-10 \mathrm{~Hz}$ stimulation.

\section{MATERIALS AND METHODS}

Slice preparation. The preparation of brainstem slices from 8- to 11-d-old Wistar rats followed the procedure described by Forsythe and BarnesDavies (1993) and Borst et al. (1995). Rats were decapitated, and the brainstem was immersed in ice-cold low-calcium artificial CSF (aCSF) 
containing (in $\mathrm{mM}$ ): $\mathrm{NaCl} 125, \mathrm{KCl} 2.5, \mathrm{MgCl}_{2} 3.0, \mathrm{CaCl}_{2} 0.1$, glucose 25 $\mathrm{NaHCO}_{3} 25, \mathrm{NaH}_{2} \mathrm{PO}_{4} 1.25$, ascorbic acid 0.4, myo-inositol 3, and Napyruvate $2, \mathrm{pH} 7.4$, when bubbled with carbogen $\left(95 \% \mathrm{O}_{2} / 5 \% \mathrm{CO}_{2}\right)$, with osmolarity $\approx 320 \mathrm{mOsm}$. Alternatively, a low-sodium $(0 \mathrm{NaCl})$, high-sucrose $(250 \mathrm{~mm})$ aCSF was used sometimes. The brainstem, with cerebellum, was glued with cyanoacrylate glue onto the stage of a vibratome slicer (Campden Instruments), and 200- $\mu \mathrm{m}$-thick transverse slices were cut proceeding from a caudal to rostral direction. Three to four slices containing the MNTB and the presynaptic axons of the calyx of Held thus were obtained. Slices were transferred rapidly to an incubation chamber containing normal aCSF gently bubbled with carbogen and maintained at $37^{\circ} \mathrm{C}$ for $30-60 \mathrm{~min}$ and were used for experiments during the next 5-6 hr. The normal aCSF was the same as the lowcalcium aCSF described above except that $1.0 \mathrm{mM} \mathrm{MgCl}_{2}$ and $2.0 \mathrm{~mm}$ $\mathrm{CaCl}_{2}$ were used.

Electrophysiology and optics. All recordings were done in normal aCSF at room temperature $\left(21-25^{\circ} \mathrm{C}\right)$. The standard patch pipette solution consisted of (in mM): K-gluconate 115, $\mathrm{KCl} 20, \mathrm{Na}_{2}$-phosphocreatine 10 , HEPES 10, EGTA-K 4 5, ATP-Mg 4, and GTP 0.3, pH 7.2 with $\mathrm{KOH}$. The final osmolarity was $\approx 295 \mathrm{mOsm}$. Some experiments also were done with Cs-gluconate or $\mathrm{CsCl}$ instead of $\mathrm{K}$-gluconate. Slices were placed in a recording chamber and held in place by a platinum grid while normal aCSF solution was perfused at a rate of $\approx 1 \mathrm{ml} / \mathrm{min}$ by a gravity-fed system of syringes and Teflon tubing. The level of solution was kept constant by a negative feedback pressure-sensitive system. Slices were visualized by IR-DIC microscopy (Stuart et al., 1993) through a $40 \times$ or $63 \times$ water immersion Zeiss objective on an upright Zeiss microscope (Axioskop, Zeiss, Oberkochen, Germany). A bipolar stimulation electrode made from Teflon-coated platinum-iridium wire $(50 \mu \mathrm{m}$ thickness) was placed gently on the midline of the transverse slices. The space between the two stimulation wires was $\approx 0.5 \mathrm{~mm}$ so as to stimulate the presynaptic fiber bundles innervating the MNTB. This arrangement avoided the generation of postsynaptic antidromic action potentials. A preselection of cells within the MNTB was done by using a patch pipette for extracellular recording of action potentials elicited by afferent fiber stimulation. Only those cells that showed extracellularly recorded preand postsynaptic action potentials (Wu and Kelly, 1993; Borst et al., 1995) were chosen for whole-cell recordings. Extracellularly recorded postsynaptic action potentials displayed an increasing synaptic delay in the range of $0.5-3 \mathrm{msec}$ during $5-10 \mathrm{~Hz}$ stimulation trains. Whole-cell fast current-clamp (EPC-9 feature; data not shown) recordings of postsynaptic action potentials showed that this increase in delay is attributable to a progressively less steep rise in successive EPSPs because of synaptic depression (see Swandulla et al., 1991). Cells recorded from were situated on the slice surface or one to two cell layers $(\approx 50 \mu \mathrm{m})$ deep within the slice.

Patch pipettes were pulled from borosilicate glass (Hilgenberg, Malsfeld, Germany) and were coated with low-melting-point dental wax or Sylgard, followed by brief fire polishing. The open tip resistance was 3-5 $\mathrm{M} \Omega$, and uncompensated access resistance was 5-10 $\mathrm{M} \Omega$ after whole-cell break-in. Seal resistances were in the range of $1-10 \mathrm{G} \Omega$ in the cellattached mode, whereas in whole-cell the leak currents varied from 100 $\mathrm{pA}$ to $1 \mathrm{nA}$ in the data set accepted for analysis. However, the large majority of the cells that were analyzed had leak currents of $100-400 \mathrm{pA}$ with the K-gluconate-based pipette solution. Cells were voltage-clamped at a holding potential of $-80 \mathrm{mV}$ if not stated otherwise. During many whole-cell recordings the series resistance $\left(R_{\mathrm{s}}\right)$ tended to increase gradually. For pharmacological experiments for which stable EPSC had to be recorded over prolonged times ( $\geq 30 \mathrm{~min}$; see Fig. $5 A$ ), $R_{\mathrm{S}}$ was monitored by a $3 \mathrm{msec}$ hyperpolarizing $(-5 \mathrm{mV})$ prepulse applied before each stimulus. In the event of a change in $R_{\mathrm{s}}$, the $R_{\mathrm{s}}$ compensation of the EPC-9 amplifier was changed such that the compensated value was kept constant $(\approx 5 \mathrm{M} \Omega)$. In other experiments that did not require comparing EPSC amplitudes over prolonged times, $R_{\mathrm{s}}$ compensation was switched to maximal values (up to $90 \%$ with a $10 \mu \mathrm{sec}$ delay), giving compensated series resistances of 1-2 M $\Omega$. For these values and EPSC amplitudes of $8 \mathrm{nA}$ (e.g., see Fig. 1), we estimate that the error in the clamp voltage at the peak of an EPSC is $\approx 10-20 \mathrm{mV}$. No corrections were made for liquid junction potentials.

Stimulation pulses applied through a Master-8 Stimulator (AMPI, Jerusalem, Israel) had a duration of $100 \mu \mathrm{sec}$ and amplitudes of 2-20 V. Stimulation pulses were controlled by a Macintosh computer (Quadra 960) running Pulse software (HEKA Electronics, Lambrecht/Pfalz, Germany), and signals were recorded via an EPC-9 (HEKA) patch-clamp amplifier. Sampling rates and filter settings were 50 and $5 \mathrm{kHz}$ and 10 and
$2 \mathrm{kHz}$ for AMPA and NMDA receptor-mediated EPSCs, respectively. To induce synaptic depression, we applied trains of $n=30$ stimuli at different frequencies, and peak EPSC amplitudes were measured after leak correction with the Pulse program. The peak amplitudes were plotted as a function of time and fit with an exponential function by IgorPro software (Wavemetrics, Lake Oswego, OR). The steady-state value of the exponential fit was taken as the EPSC amplitude at the end of the trains $\left(I_{\mathrm{ss}}\right.$; see Fig. $1 C$, for an example). To calculate the amount of depression, we divided $I_{\mathrm{ss}}$ by $I_{\mathrm{o}}$, the peak amplitude of the first EPSC in a train. For the NMDA component of the EPSCs measured at +60 or $+80 \mathrm{mV}$, peak amplitudes were measured in a time window between 10 and $20 \mathrm{msec}$ after the stimulus artifact (see Fig. 4A). Because of the slow decay kinetics of the NMDA receptor-mediated EPSC, a residual current of $5 \pm 4 \%(n=6$ cells $), 7 \pm 3 \%(n=3$ cells $)$, and $33 \pm 8 \%(n=4$ cells $)$ of $I_{\mathrm{o}}$ was observed at the onset of the second EPSC with stimulation intervals of $1 \mathrm{sec}(1 \mathrm{~Hz}), 0.5 \mathrm{sec}(2 \mathrm{~Hz})$, and $200 \mathrm{msec}(5 \mathrm{~Hz})$, respectively. Average data are reported as mean $\pm \mathrm{SD}$ values.

Drugs. D(-)-2-Amino-5-phosphonopentanoic acid (D-AP5), 6-cyano7-nitroquinoxaline-2,3-dione (CNQX), (1S,3S)-1-aminocyclopentane1,3-dicarboxylic acid (ACPD), L(+)-2-amino-4-phosphonobutyric acid

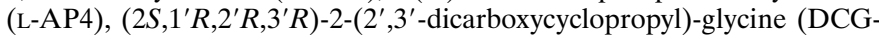
IV), and CPPG were purchased from Tocris Cookson (Bristol, UK). Strychnine was obtained from Research Biochemicals (Natick, MA), and all other drugs and chemicals were from Sigma (Deisenhofen, Germany) except purified Cs-gluconate salt, which was kindly provided by Dr. J. G. G. Borst (Max-Planck-Institute, Heidelberg, Germany).

\section{RESULTS}

\section{Properties of synaptic depression at the calyx of Held}

A single presynaptic action potential elicits a large and rapidly decaying EPSC in the principal cells of the rat MNTB under whole-cell voltage clamp (Forsythe and Barnes-Davies, 1993; Borst et al., 1995). Such large EPSCs are typical of calyx-type synapses (Trussell et al., 1993; Yawo and Momiyama, 1993; Isaacson and Walmsley, 1995; Zhang et al., 1996). Examples of EPSCs elicited by afferent fiber stimulation are shown in Figure $1, A$ and $B$. Successive EPSCs recorded in $2 \mathrm{~mm}[\mathrm{Ca}]_{\mathrm{o}}$ and $1 \mathrm{~mm}$ $[\mathrm{Mg}]_{\mathrm{o}}$ under voltage clamp at a holding potential of $-80 \mathrm{mV}$ decreased in amplitude during 0.5 and $10 \mathrm{~Hz}$ stimulation trains. The degree of synaptic depression was larger for $10 \mathrm{~Hz}$ than for $0.5 \mathrm{~Hz}$, as is indicated in Figure $1 C$. EPSCs had a fast decay time (exponential time constant $\tau \approx 1.1 \mathrm{msec}$ ) and were blocked by CNQX (5 $\mu \mathrm{M}$; data not shown), identifying them as AMPA/ kainate receptor-mediated EPSCs. From here onward, these fast EPSCs will be termed AMPA EPSCs.

After trains of presynaptic stimuli at frequencies varying from 0.2 to $100 \mathrm{~Hz}$, AMPA EPSCs strongly depressed with the first EPSCs $I_{\mathrm{o}}$ in a train of stimuli decaying to a new steady-state value, $I_{\mathrm{ss}}$ (Fig. $1 C$ ). The amount of AMPA EPSC depression, expressed as the ratio $I_{\mathrm{ss}} / I_{\mathrm{o}}$, was dependent on the frequency of stimulation (Fig. $2 A$, open symbols). In the example of Figure $1 C$, $I_{\mathrm{ss}} / I_{\mathrm{o}}$ was 0.67 and 0.23 for stimulation frequencies of 0.5 and 10 $\mathrm{Hz}$, respectively. At $100 \mathrm{~Hz}$, depression was found to be $0.08 \pm$ 0.03 for $I_{\mathrm{ss}} / I_{\mathrm{o}}(n=5$ cells; see also Fig. 11 in Borst et al., 1995). The frequency at which half-maximal depression is observed therefore was close to $1 \mathrm{~Hz}$ (see Fig. $2 A$ ). This contrasts with the chick magnocellularis calyx synapse, where half-maximal depression was observed at $\approx 50 \mathrm{~Hz}$ (Zhang and Trussell, 1994). The solid line in Figure $2 A$ is a two-exponential function best fit, which includes the $100 \mathrm{~Hz}$ data point. A single exponential function could not fit the data points from 0.2 to $10 \mathrm{~Hz}$ very well, especially when the $100 \mathrm{~Hz}$ data were included (data not shown). It also should be noted that the amount of depression, analyzed at frequencies of 5 and $10 \mathrm{~Hz}(n=24$ cells; Fig. $2 B)$, was correlated with the amplitude of the first EPSC in a train. Thus, different cells had different initial EPSC amplitudes (range 1-11 nA), and 


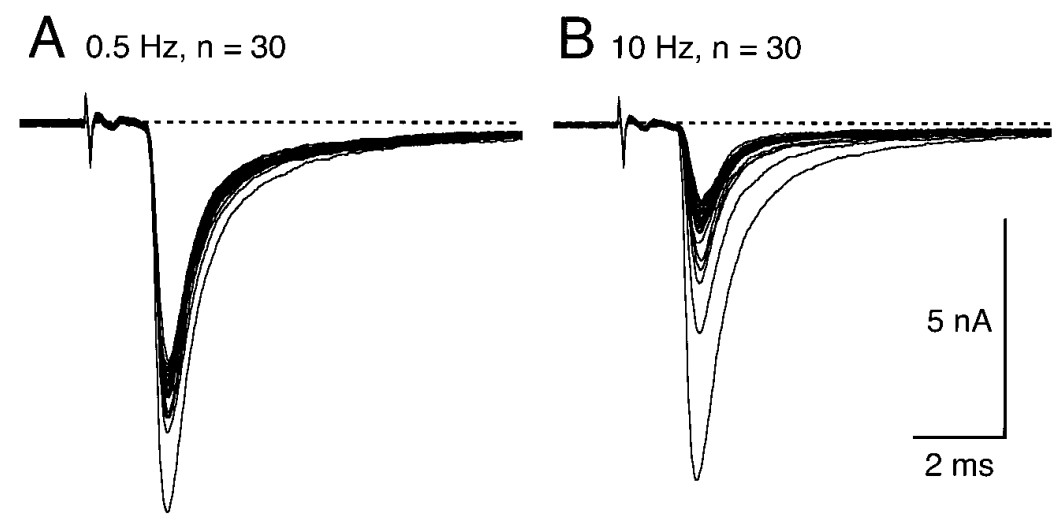

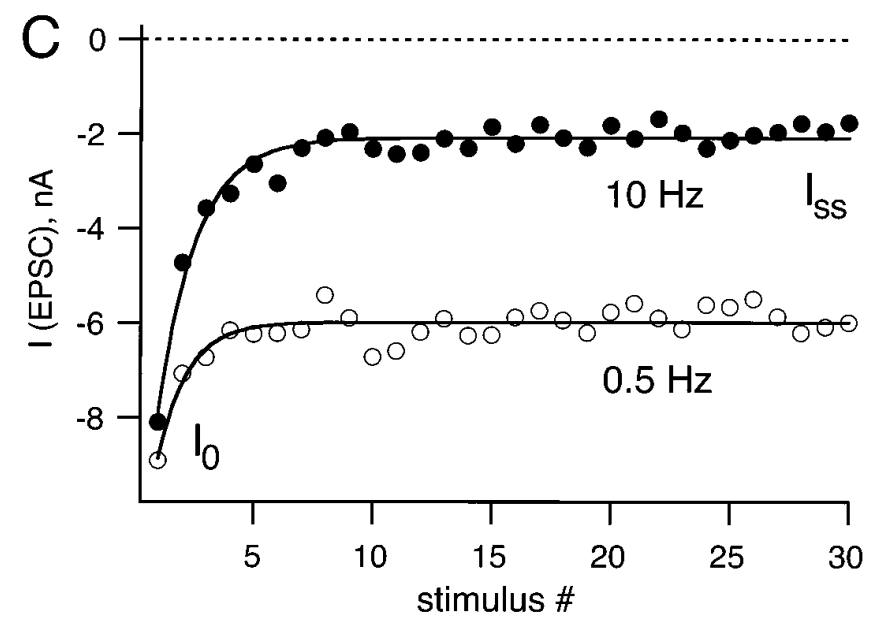

for large initial EPSCs we observed a larger degree of depression than for small initial EPSC amplitudes (Fig. 2B).

The finding that a robust form of synaptic depression can be induced at intermediate stimulation frequencies of $1-10 \mathrm{~Hz}$ suggests that the recovery rate from depression is slow. Interestingly, a strong depression of AMPA receptor-mediated EPSCs with a fast time course of recovery $\left(\approx 15 \mathrm{msec}\right.$ at $30^{\circ} \mathrm{C}$; Trussell et al., 1993) has been described in a chick calyx synapse, and this form of synaptic depression has been linked to desensitization of postsynaptic AMPA receptors. We therefore measured the recovery time constant for synaptic depression elicited at intermediate stimulation frequencies. A conditioning train of 30 pulses at $10 \mathrm{~Hz}$ was followed by a single test pulse given at a variable time interval after the end of the stimulus train. A waiting period of 30 sec was used between the single test pulse and a subsequent conditioning train. An example of depression at $10 \mathrm{~Hz}$, followed by recovery measured at time intervals $\Delta t$ in the range of $0.5-16$ sec, is shown in Figure $3 A$. After a recovery time of $0.5 \mathrm{sec}$, only $\approx 10 \%$ of the depression has recovered, and the complete time course of recovery was well fit by a single exponential with a time constant $\tau=4.2 \mathrm{sec}$ (Fig. $3 B$ ). This time constant of recovery was independent of the amplitude of the initial EPSC in the $10 \mathrm{~Hz}$ train or the amount of overall depression.

\section{Depression of NMDA receptor-mediated EPSCs}

The recovery from synaptic depression at $10 \mathrm{~Hz}$ is significantly slower than the recovery from AMPA receptor desensitization, which is in the range of $10-300 \mathrm{msec}$ for various native and recombinant AMPA receptors (Colquhoun et al., 1992; Trussell et al., 1993; Lomeli et al., 1994). We therefore studied NMDA
Figure 1. Synaptic depression in principal neurons of the rat MNTB. $A$, An example of EPSCs elicited by afferent fiber stimulation trains of 30 stimuli at $0.5 \mathrm{~Hz}$. Voltage-clamp recordings were made at a holding potential of $-80 \mathrm{mV}$ in 2 $\mathrm{mm}[\mathrm{Ca}]_{\mathrm{o}}$ and $1 \mathrm{~mm}[\mathrm{Mg}]_{\mathrm{o}}$. Note that the first EPSC in the train is the largest and that the onset of the EPSCs was $\approx 1.5$ msec after the stimulus artifact. $B$, In the same cell as in $A$, EPSCs were elicited by 30 stimuli at $10 \mathrm{~Hz}$. $C$, The peak EPSC amplitude of examples $A$ and $B$ are plotted for $0.5 \mathrm{~Hz}$ (open symbols) and $10 \mathrm{~Hz}$ (closed symbols). These AMPA receptor-mediated EPSCs depressed from the initial amplitude $\left(I_{0}\right)$ to a new steady-state value $\left(I_{\mathrm{ss}}\right)$, which was obtained from the steady-state value of an exponential fit (solid line; $\tau$ $=2.47 \mathrm{sec}$ for $0.5 \mathrm{~Hz}$ and $\tau=159 \mathrm{msec}$ for $10 \mathrm{~Hz}$ ).

receptor-mediated EPSCs (Forsythe and Westbrook, 1988) to determine whether depression results from a reduction in glutamate release. It has been shown previously that manipulations that reduce the amount of presynaptic glutamate release lead to a parallel reduction of the AMPA and the NMDA components of the EPSC [see Perkel and Nicoll (1993) and Tong and Jahr (1994a) and references therein]. Therefore, if depression is attributable to presynaptic mechanism(s), it also should be observable for the NMDA component of the EPSC.

EPSCs were elicited in $2 \mathrm{~mm}[\mathrm{Ca}]_{\mathrm{o}}$ and $1 \mathrm{~mm}[\mathrm{Mg}]_{\mathrm{o}}$ at positive holding potentials $(+60$ or $+80 \mathrm{mV})$. Under these conditions a dual component EPSC was observed, which consisted of the fast AMPA component as well as of a more slowly rising and decaying component (Hestrin et al., 1990; Forsythe and Barnes-Davies, 1993), which was largely blocked by $50 \mu \mathrm{M}$ D-AP5 and thus was mediated by NMDA receptors. Repetitive stimulation at $1 \mathrm{~Hz}$ induced depression of the NMDA component to a value of $I_{\mathrm{ss}} / I_{0}$ $=0.59$ in the example of Figure $4 A$. The inset in Figure $4 A$ displays the same data on an expanded time scale and shows that the NMDA receptor-mediated currents peaked at $\approx 16 \mathrm{msec}$ after the peak of the AMPA receptor-mediated currents. In the same cell the amount and the time course of depression of the peak AMPA component (measured at $-80 \mathrm{mV}$; Fig. $4 B$, open symbols) were found to be similar to the depression of the peak NMDA component (Fig. 4B, closed symbols). In six cells in which depression was measured at $1 \mathrm{~Hz}, I_{\mathrm{ss}} / I_{\mathrm{o}}$ was $0.47 \pm 0.09$ for AMPA EPSC and $0.51 \pm 0.05$ for NMDA EPSC and thus not significantly different (see Fig. $2 A$ ). Similar results also were obtained for $2 \mathrm{~Hz}$ $\left(I_{\mathrm{ss}} / I_{\mathrm{o}}=0.33 \pm 0.05\right.$ for NMDA EPSC; $\left.n=3\right)$ and $5 \mathrm{~Hz}\left(I_{\mathrm{ss}} / I_{\mathrm{o}}=\right.$ 

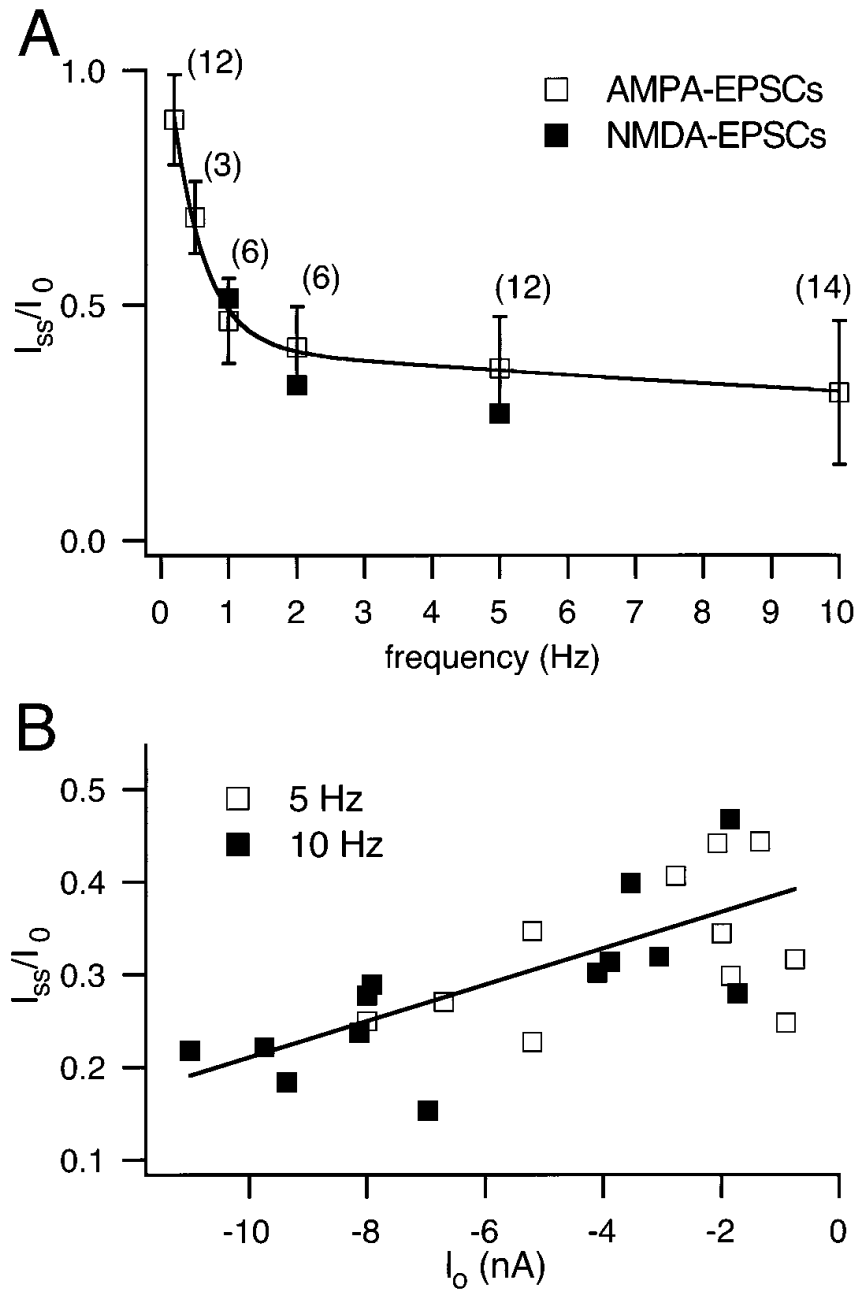

Figure 2. Frequency dependence of synaptic depression. $A$, The amount of depression of AMPA EPSCs, expressed as $I_{\mathrm{ss}} / I_{0}$, as a function of stimulus frequency in a range of $0.2-10 \mathrm{~Hz}$ (open symbols). The number of cells for each frequency is indicated in parentheses; the total number of cells was $n=36$. Note that the average data for the depression of NMDA EPSC obtained at 1,2, and $5 \mathrm{~Hz}$ are added also (closed symbols). The solid line is a fit to a double exponential function, which included the value of $I_{\mathrm{ss}} / I_{0}$ at $100 \mathrm{~Hz}$. B, Correlation of the amount of depression $I_{\mathrm{ss}} / I_{0}$ and the initial peak EPSC amplitude $I_{0}$. Data for $10 \mathrm{~Hz}(n=13$; closed symbols $)$ and $5 \mathrm{~Hz}(n=11$; open symbols $)$ were pooled and fit by linear regression.

$0.27 \pm 0.08$ for NMDA EPSC; $n=4$ ) stimulation frequencies. However, at $5 \mathrm{~Hz}$ the slowly decaying NMDA baseline current (see Fig. $4 A$ ) resulted in a large residual current $(\approx 33 \%$ of NMDA $I_{\mathrm{o}}$; see Materials and Methods) that had to be subtracted systematically. At the short stimulus intervals during $5 \mathrm{~Hz}$ stimulation, a slight overestimation of the degree of depression might occur, because NMDA channels that are still open after the first release event might not be activated (Lester et al., 1990).

NMDA receptors show different forms of desensitization that potentially can contribute to depression of NMDA EPSCs. For example, at subsaturating glycine concentrations (Johnson and Ascher, 1987) a strong form of desensitization has been described (Benveniste et al., 1990). Therefore, in two cells we added a suprasaturating glycine concentration to the slice $(100 \mu \mathrm{M}$ glycine in the presence of $2 \mu \mathrm{M}$ strychnine), but we found that the depression of NMDA EPSCs was not changed. Also, a Cainduced desensitization of NMDA receptors (Legendre et al.,
1993) should not be involved, because NMDA-mediated Ca influx is negligible at positive membrane potentials of approximately $+60 \mathrm{mV}$ (Schneggenburger et al., 1993), and 5 mM EGTA was included in the patch pipette solution (see Materials and Methods). Thus the simplest interpretation of the finding that AMPA and NMDA components of the EPSC show similar amounts of depression is that the amount of glutamate release is reduced during synaptic depression.

\section{CPPG is a potent mGluR antagonist}

A possible presynaptic mechanism for depression is the activation of autoreceptors, negatively coupled to release, by spillover of neurotransmitter from the synaptic cleft (Scanziani et al., 1997). In the calyx of Held, activation of metabotropic glutamate receptors by synthetic agonists has been shown to inhibit synaptic transmission via a presynaptic mechanism (Barnes-Davies and Forsythe, 1995) involving an inhibition of voltage-gated $\mathrm{Ca}^{2+}$ currents (Takahashi et al., 1996). However, a potent antagonist for mGluRs has been lacking for the calyx of Held synapse. The widely used antagonist $(R, S)$ - $\alpha$-methyl-4-carboxyphenylglycine (MCPG) (Glaum and Miller, 1993; Bolshakov and Siegelbaum, 1994; Burke and Hablitz, 1994; Maki et al., 1995; Scanziani et al., 1997) was ineffective at the calyx of Held (Barnes-Davies and Forsythe, 1995) even at $0.5-1 \mathrm{~mm}$ concentrations. We therefore have studied the actions of a more recently synthesized competitive antagonist of group II and group III mGluRs, CPPG (Jane et al., 1996).

EPSCs were elicited every $5 \sec$ (Fig. $5 A$ ) and were found to be reversibly reduced by L-AP4 and ACPD. On average, peak AMPA EPSCs were reduced from a $100 \%$ control value to $34 \pm$ $6 \%(n=9)$ and $53 \pm 11 \%(n=4)$ with L-AP4 $(50 \mu \mathrm{M})$ and ACPD $(50 \mu \mathrm{M})$, respectively (Fig. $6 B)$. DCG-IV, a high-affinity group II agonist, reduced EPSCs to $60 \pm 7 \%(n=5)$ at the relatively high dose of $5 \mu \mathrm{M}$ and to $39 \pm 6 \%(n=3)$ at $10 \mu \mathrm{M}$, but it has been reported that DCG-IV might inhibit EPSCs via activation of NMDA receptors (Breakwell et al., 1997) (see, however, Macek et al., 1996) at $\approx 10 \mu \mathrm{M}$, so we did not study its effects further. In contrast to MCPG (Barnes-Davies and Forsythe, 1995), we found that CPPG reversed the agonist action of L-AP4 in a dosedependent manner. At concentrations of 10 and $30 \mu \mathrm{M}, \mathrm{CPPG}$ partially reversed the effect of $50 \mu \mathrm{M}$ L-AP4 (see Fig. $5 A$ for an example of $30 \mu \mathrm{M}$ ), whereas at $300 \mu \mathrm{M} \mathrm{CPPG}$ restored the EPSC amplitude to $104 \pm 4 \%(n=2)$ of control (Figs. $5 B, 6 B)$. In the presence of CPPG the EPSC decay kinetics were similar to control conditions (Fig. 5C). The dose-response curve of this CPPG effect is shown in Figure $6 A$; the data were fit by a Hill function with a half-maximal active concentration of $25 \mu \mathrm{M}$ and a Hill coefficient of 1.5. CPPG also reversed the inhibition induced by $50 \mu \mathrm{M}$ ACPD to a value of $99 \pm 11 \%$ of control (see Fig. $6 B$ ). These findings are in agreement with the competitive antagonism of CPPG at group II and group III mGluRs reported by Jane et al. (1996) in the spinal cord of 1- to 5-d-old rats. CPPG is thus a potent antagonist of mGluRs at the calyx of Held.

\section{Effects of CPPG on synaptic depression}

We next asked to what extent CPPG-sensitive mGluRs contribute to synaptic depression. Given that the affinities of recombinantly expressed group II and group III mGluRs for ACPD and L-AP4, respectively, are comparable or even higher than for the putative transmitter L-glutamate (Tanabe et al., 1993) (for review, see Saugstad et al., 1995), a concentration of $300 \mu \mathrm{M}$ CPPG should be very effective in blocking the activa- 

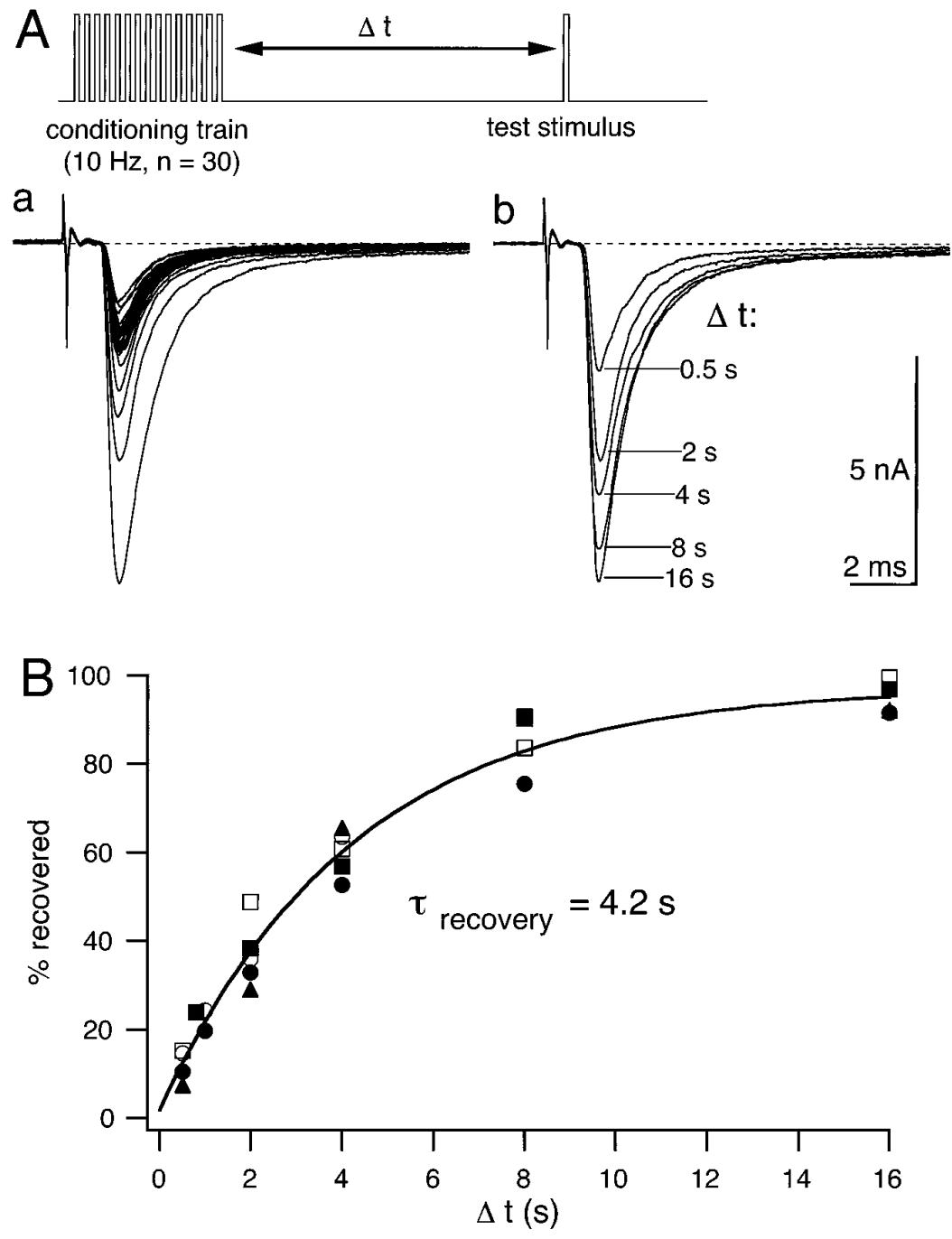

Figure 3. Recovery time course from depression induced at $10 \mathrm{~Hz}$. Conditioning trains of 30 stimuli at $10 \mathrm{~Hz}$ were followed by single test stimuli at varying intervals from 0.5 to $16 \mathrm{sec} . A a$, A representative example of AMPA EPSCs recorded at a holding potential of -80 $\mathrm{mV}$ during a conditioning train. $A b$, Five AMPA EPSCs recorded in the same cell as for $A a$ after recovery intervals $\Delta t$ varying between 0.5 and $16 \mathrm{sec}$. Note that after 0.5 sec only $\approx 15 \%$ of the decrement in EPSC amplitude induced by depression has recovered. $B$, Recovery time course from depression, expressed as the percentage of EPSC decrement $\left(I_{\mathrm{d}}=I_{0}-I_{\mathrm{ss}}\right.$; see also Fig. $\left.7 B\right)$. Data from five cells were fit by a single exponential function with a time constant $\tau=4.2 \mathrm{sec}$. tion of mGluRs by glutamate spillover from the synaptic cleft. To test the action of CPPG on synaptic depression, we applied 5 or $10 \mathrm{~Hz}$ trains of $n=30$ stimuli at intervals of $\approx 45 \mathrm{sec}$ to allow for the complete recovery of depression in between the trains. After having obtained a few examples of depression in control conditions, we applied $300 \mu \mathrm{M}$ CPPG to the slice. As can be seen in Figure $7 A$ in which $I_{\text {ss }}$ and $I_{0}$ were plotted normalized to the average value of the corresponding control group, CPPG induced a small but significant increase in $I_{\text {ss }}$ (1.25-fold over control; $n=4$ cells), whereas $I_{0}$ was unaffected. The small effect of CPPG on depression is shown in Figure $7 B$ for one cell in which the peak EPSC amplitudes from $n=4$ trains were averaged for control conditions (open symbols) and for $300 \mu \mathrm{M} \mathrm{CPPG} \mathrm{(closed} \mathrm{symbols).} \mathrm{To} \mathrm{compare} \mathrm{the} \mathrm{amount} \mathrm{of}$ depression under these two conditions, we calculated the decrement $I_{\mathrm{d}}$ in EPSC amplitude $\left(I_{\mathrm{d}}=I_{0}-I_{\mathrm{ss}}\right.$; see Fig. $\left.7 B\right)$. In the cell shown in Figure $7 B$, the decrement was $1.03 \mathrm{nA}$ in control and $0.90 \mathrm{nA}$ in the presence of CPPG and thus was reduced by $12 \%$. On average, the value of $I_{\mathrm{d}}$ was found to be reduced by $6.2 \pm 2.5 \%\left(n=4\right.$ cells, with $I_{0}=1.8,2.7,4$, and $\left.8 \mathrm{nA}\right)$ when $300 \mu \mathrm{M} \mathrm{CPPG}$ was applied. These results suggest that CPPGsensitive mGluRs contribute on the order of $10 \%$ or less to the overall depression elicited by $5-10 \mathrm{~Hz}$ stimulation of the calyx of Held.

\section{DISCUSSION}

\section{Depression is mediated mainly by presynaptic mechanism(s)}

Frequency-dependent depression is a major form of short-term plasticity at the calyx of Held synapse. We have found robust depression of AMPA and NMDA receptor-mediated EPSCs over a wide range of frequencies $(0.2-100 \mathrm{~Hz})$ but have studied mostly the synaptic depression elicited by $5-10 \mathrm{~Hz}$ trains, partly because this type of depression can be dissociated from facilitation, whereas at higher stimulation frequencies both phenomena occur simultaneously, complicating an analysis of their underlying mechanisms. At $100 \mathrm{~Hz}$, for example, a facilitated second EPSC sometimes is observed [see Borst et al. (1995), their Fig. $11 A]$. Furthermore, recently Helmchen et al. (1997) showed that the $[\mathrm{Ca}]_{\mathrm{i}}$ transient within the calyx of Held, triggered by a single action potential, returns to resting levels after $\approx 100 \mathrm{msec}$, so that a rapid buildup of presynaptic $[\mathrm{Ca}]_{i}$, which could lead to facilitation (Zucker, 1989; Atluri and Regehr, 1996), may not occur for 5-10 Hz stimulation frequencies. In addition, presynaptic calcium current inactivation caused by calcium influx (Yawo and Momiyama, 1993; von Gersdorff and Matthews, 1996) is probably not significant at lower stimulation frequencies, thus simplifying the analysis of synaptic depression. Calcium current inactivation in 

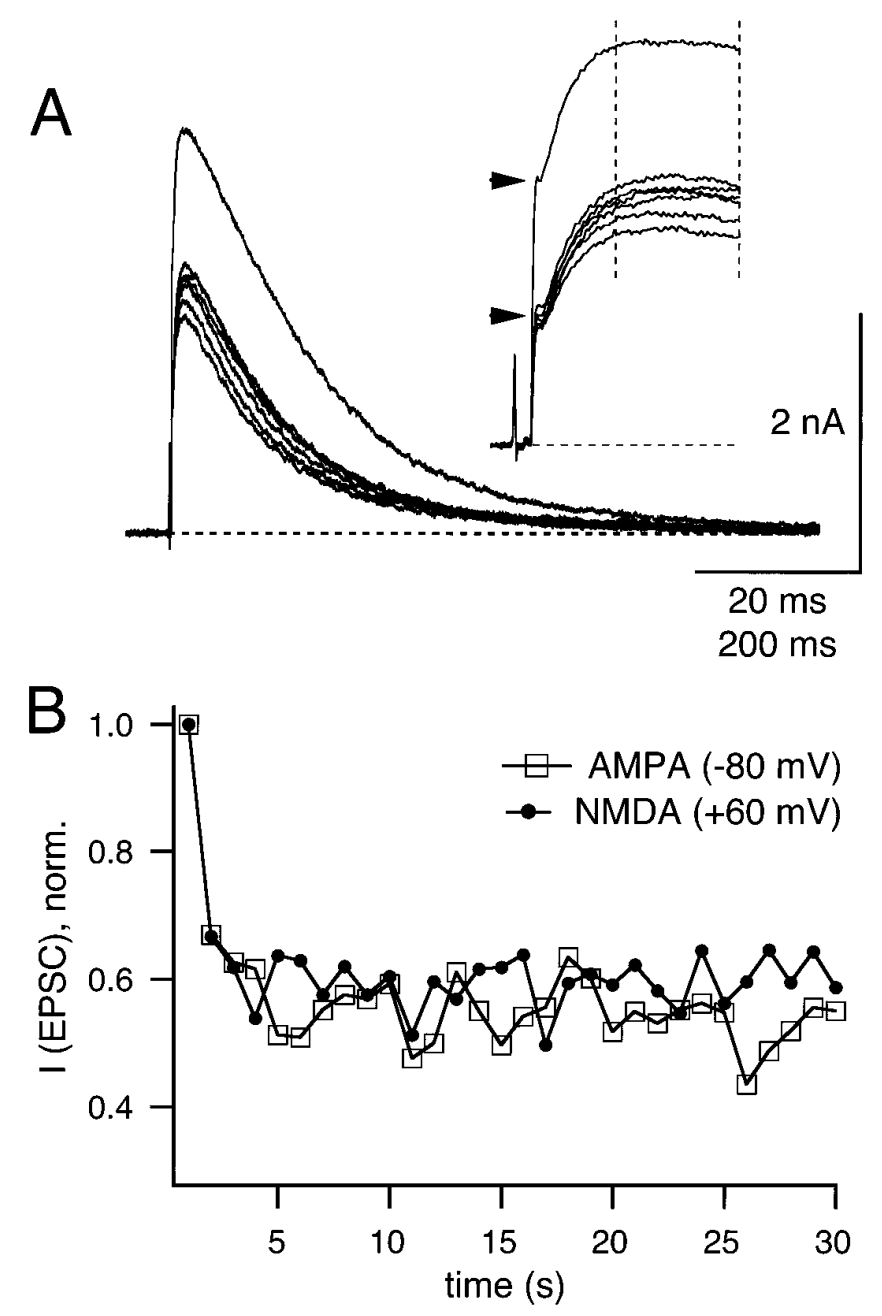

Figure 4. Depression of NMDA receptor-mediated EPSCs. A, EPSCs were elicited at $1 \mathrm{~Hz}$ at a holding potential of $+60 \mathrm{mV}$. The first seven traces in a train of 30 stimuli are shown. A Cs-gluconate-based internal pipette solution was used (see Materials and Methods), and $100 \mu \mathrm{M}$ glycine plus $2 \mu \mathrm{M}$ strychnine were added to the external solution. Inset shows the initial part of the same data on an expanded time scale (time $b a r=20 \mathrm{msec}$ ). The horizontal arrowheads indicate the peak amplitude of the first and the depressed AMPA receptor-mediated component of the EPSCs at a holding potential of $+60 \mathrm{mV}$. The vertical dotted lines on the inset indicate the time window from which the peak NMDA receptormediated component of the EPSC was obtained. $B$, Time course of depression of NMDA EPSC (closed symbols) and AMPA EPSCs (open symbols; recorded at $-80 \mathrm{mV}$ ) for a $1 \mathrm{~Hz}$ train recorded from the same cell as shown in $A$. EPSC amplitude values were normalized to $I_{0}$.

fact has been ruled out as a factor causing depression in the giant synaptic terminals of goldfish bipolar neurons (von Gersdorff and Matthews, 1997).

The degree of depression of EPSCs as assayed by the ratio $I_{\mathrm{ss}} / I_{0}$ depended strongly on stimulation frequencies ranging from 0.2 to $1 \mathrm{~Hz}$ (Fig. 2A). Half-maximal depression was observed already at $\approx 1 \mathrm{~Hz}$. This contrasts with recently reported experiments on depression of evoked field potentials and EPSPs in pyramidal neurons of the rat neocortex, where half-maximal depression was observed at 10-15 Hz (Abbott et al., 1997; Tsodyks and Markram, 1997). The initial steep dependence of EPSC depression on frequencies ranging from 0.2 to $1 \mathrm{~Hz}$ can be accounted for by the recovery time constant from depression that we independently measured $(\tau=4.2 \mathrm{sec}$; Fig. $3 B)$; however, for the depression elicited at frequencies larger than $2 \mathrm{~Hz}$, this relatively slow recovery rate cannot account for the observed degree of depression. The shallow dependence of depression on frequencies in the range from $2-10 \mathrm{~Hz}$ (see Fig. $2 A$ ) is compatible with the hypothesis of an accelerated recovery or recruitment process during the stimulation train as proposed by Kusano and Landau (1975) for the squid giant synapse.

We have shown that AMPA and NMDA receptor-mediated EPSCs were depressed in a parallel manner for $1-5 \mathrm{~Hz}$ stimulation frequencies. AMPA and NMDA receptors are thought to be colocalized in the synaptic cleft (Bekkers and Stevens, 1989; Jones and Baughman, 1991). NMDA receptors, however, show less complete and slower desensitization (Benveniste et al., 1990; Legendre et al., 1993) than AMPA receptors, and under our recording conditions desensitization of NMDA receptors should have been negligible. Thus, the simplest interpretation of the finding that AMPA and NMDA EPSCs are depressed in parallel is that presynaptic mechanism(s) are responsible for depression.

The recovery rate from $5-10 \mathrm{~Hz}$ depression for AMPA EPSCs that we measured was $\tau=4.2 \mathrm{sec}$. Similar recovery time constants were reported in the squid giant synapse $(\tau=4.9 \mathrm{sec}$; Kusano and Landau, 1975), the frog neuromuscular junction $(\tau=5 \mathrm{sec}$; Betz, 1970; Magleby, 1987), and cultured hippocampal neurons $(\tau=$ $8-12$ sec; Stevens and Tsujimoto, 1995). Recovery from depression is, however, faster in pyramidal neurons of the neocortex $(\tau=$ 300-960 msec; Abbott et al., 1997; Tsodyks and Markram, 1997). Our time constant of $4.2 \mathrm{sec}$ also contrasts with the recovery from AMPA receptor desensitization in outside-out patches from the chick magnocellularis neurons (Trussell et al., 1993), which was found to be $\approx 20 \mathrm{msec}$ at room temperature. Furthermore, one of the AMPA receptor subunits likely to be expressed in rat MNTB principal neurons, GluR-D flop (Geiger et al., 1995), displays rapid recovery from desensitization when tested in a recombinant system $\left(\tau_{\text {rec }}=30-50\right.$ msec; Lomeli et al., 1994). Recent experiments using flash photolysis of caged glutamate in the chick magnocellularis calyx by Otis et al. (1996) also shows that AMPA receptormediated EPSCs recover completely from desensitization within $\approx 60 \mathrm{msec}$. This further suggests that depression at $5-10 \mathrm{~Hz}$ is not attributable to postsynaptic receptor desensitization. We emphasize, however, that at higher stimulation frequencies (e.g., at 100 $\mathrm{Hz}$ ) desensitization might become a significant factor in AMPA receptor-mediated EPSC depression (Trussell et al., 1993). Thus at different stimulus frequencies different mechanisms may operate to produce synaptic depression.

\section{mGluRs contribute a small amount to depression}

Activation of autoreceptors that negatively regulate presynaptic $\mathrm{Ca}^{2+}$ channels or exocytosis is a possible mechanism by which depression may be induced after repeated synaptic stimulation. At the frog neuromuscular junction, for example, antagonists of adenosine autoreceptors block completely $1 \mathrm{~Hz}$-elicited shortterm depression (Redman and Silinsky, 1994). Activation of mGluRs inhibits EPSCs in hippocampal slices (Baskys and Malenka, 1991; Macek et al., 1996) and in the lamprey giant synapse (Krieger et al., 1996). At the MNTB Barnes-Davies and Forsythe (1995) have shown previously that agonists of mGluRs depress EPSCs. In addition, Takahashi et al. (1996) showed that activation of mGluRs by L-AP4 inhibits the calyx calcium current, thus making activation of mGluRs an attractive possible mechanism for depression at this synapse. We have shown, however, that CPPG-sensitive mGluRs contribute $<10 \%$ to $5-10 \mathrm{~Hz}$ induced synaptic depression. Nevertheless, if the mGluRs of the 

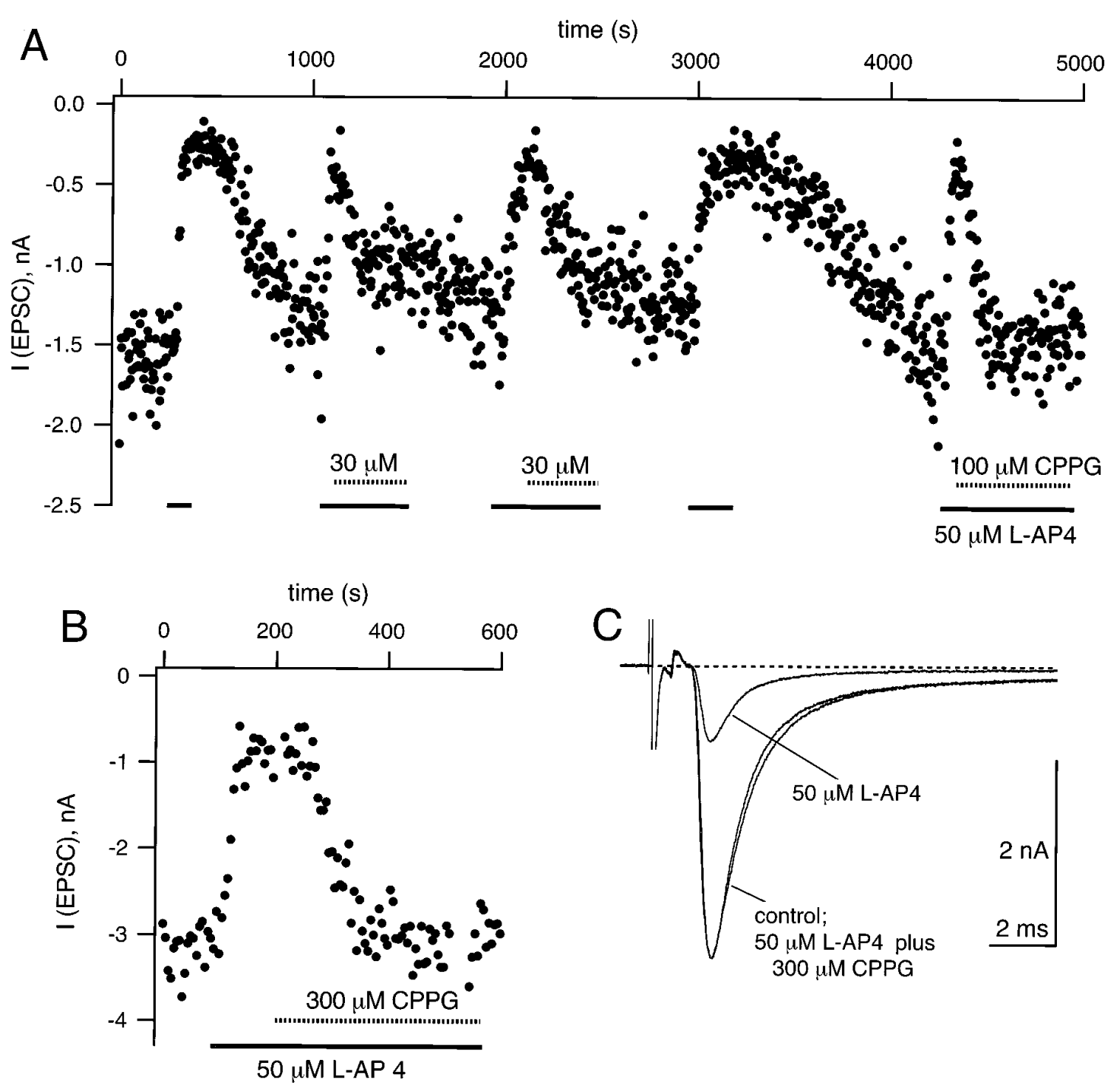

Figure 5. CPPG effectively antagonizes the depressing effects of L-AP4. A, Peak amplitudes of AMPA EPSCs elicited at $0.2 \mathrm{~Hz}$ plotted as a function of time. L-AP4 $(50 \mu \mathrm{M})$ was applied during the times indicated by the solid bars. In three instances during this experiment, 30 or $100 \mu \mathrm{M}$ CPPG (hatched bars) was applied to the slice during the continued presence of $50 \mu \mathrm{M} \mathrm{L}-\mathrm{AP} 4$. Note that the depressing effect of $50 \mu \mathrm{M}$ L-AP4 was partially recovered by $30 \mu \mathrm{M}$ CPPG and was recovered more completely by $100 \mu \mathrm{M}$ CPPG. B. An example from another cell in which $300 \mu \mathrm{M}$ CPPG reversed completely the effect of $50 \mu \mathrm{M} \mathrm{L}$-AP4. $C$, EPSCs (average traces of $n=5$ single sweeps) corresponding to the control condition, to the presence of $50 \mu \mathrm{M}$ L-AP4, and to $50 \mu \mathrm{M}$ L-AP4 in the presence of $300 \mu \mathrm{M}$ CPPG. Same cell as shown in $B$.

calyx of Held are located outside the synaptic cleft, as is the case for the mGluR2 receptors on the mossy fiber terminals of the rat hippocampus (Yokoi et al., 1996), our results confirm that glutamate spillover can activate presynaptic mGluRs (Scanziani et al., 1997), but the results argue against a tonic inhibition of release by ambient glutamate (Zorumski et al., 1996), because peak EPSCs $\left(I_{\mathrm{o}}\right)$ elicited at intervals of $\approx 45 \mathrm{sec}$ did not change in the presence of CPPG (Fig. 7A). It is possible that after prolonged activation (e.g., 900 stimuli; Kobayashi et al., 1996) mGluR-dependent longterm plasticity phenomena may be induced at the calyx of Held synapse, but we did not investigate this possibility. In addition, we emphasize that our recordings were performed at room temperature, when glutamate uptake is slowed down significantly (Tong and Jahr, 1994b; Asztely et al., 1997), so the contribution of mGluRs to short-term synaptic depression may be even smaller at the higher physiological temperature. Furthermore, we have used juvenile rats (postnatal day P8-P11) in our experiments, and certain aspects of synaptic transmission may not be developed fully at this age (Lohmann and Friauf, 1996).

\section{Implications of depression at the calyx of Held synapse}

A single synaptic terminal can be stimulated reliably at the calyx of Held. Above the stimulus threshold a single action potential is triggered through a single large-diameter axon. Dendritic filtering or attenuation of EPSCs is probably absent because of the axosomatic nature of the synaptic structure. The anomalously large number of active zones, however, makes this synapse rather unique among mammalian CNS synapses, which are typically less than a micrometer in size. The quantal content of evoked EPSCs is large ( $\approx 200$ quanta; Borst and Sakmann, 1996), although different active zones may release with different probabilities (Hessler et al., 1993; Rosenmund et al., 1993; Murthy et al., 1997). Despite its pronounced depression, the calyx of Held synapse is capable of reli- 


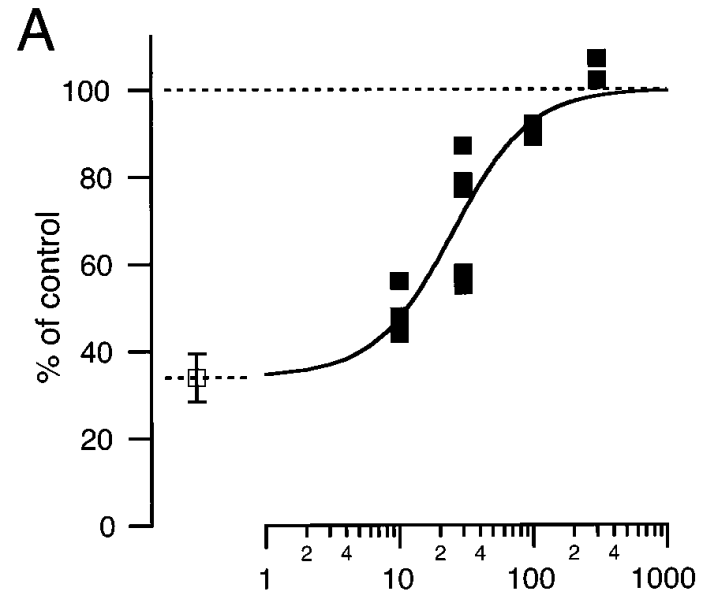

[CPPG], $\mu \mathrm{M}$

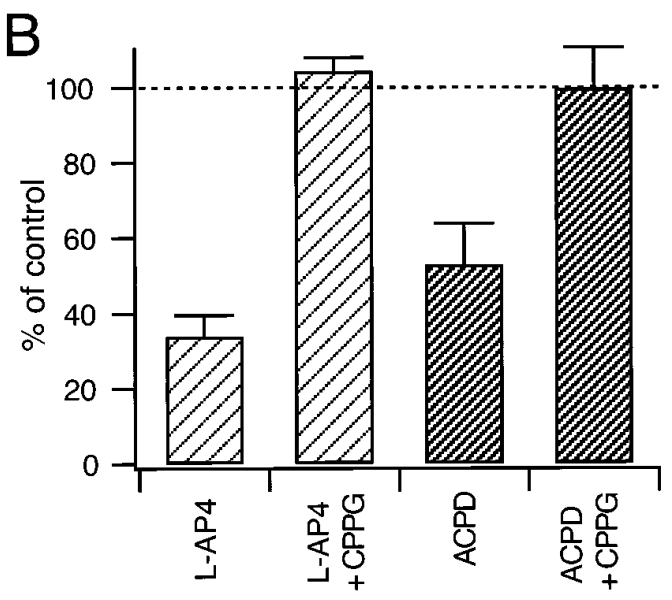

Figure 6. Summary of the antagonistic effects of CPPG. $A$, Dose-response curve for the effect of CPPG on the L-AP4-induced inhibition of EPSC amplitudes. In each cell $(n=9)$, applications of $50 \mu \mathrm{M}$ L-AP4 were followed by coapplications of $50 \mu \mathrm{M} \mathrm{L}-\mathrm{AP} 4$, together with the indicated concentration of CPPG. EPSC amplitudes were analyzed after stable values had been reached ( $\geq 1 \mathrm{~min}$ after change of solutions; see Fig. 5). The average inhibition induced by $50 \mu \mathrm{M}$ L-AP4 in the absence of CPPG $(n=9)$ is indicated by the open symbol. The solid line is drawn according to a Hill equation with a half-maximal active concentration of $25 \mu \mathrm{M}$ and a Hill coefficient of 1.5. $B$, CPPG $(300 \mu \mathrm{M})$ reversed completely the agonist effect of both L-AP4 (50 $\mu \mathrm{M} ; n=2$ cells) and ACPD (50 $\mu \mathrm{M} ; n=4$ cells).

able synaptic transmission at $200 \mathrm{~Hz}$ in the age range we have studied (Borst et al., 1995; Brew and Forsythe, 1995) at room temperature $\left(25^{\circ} \mathrm{C}\right)$; in adult animals pre- and postsynaptic action potentials can phaselock to an impressive rate of $600 \mathrm{~Hz}$ (Smith et al., 1991; Wu and Kelly, 1993) at physiological temperatures $\left(37^{\circ} \mathrm{C}\right)$. The large number of release sites therefore might be seen as a safety factor that allows reliable synaptic transmission to take place even at high frequencies when only a small fraction of synaptic vesicles might be available for release. In addition, the particular set of ion channels expressed in the postsynaptic principal neurons, some of which display rapid activation and strong outward rectification (Brew and Forsythe, 1995), may aid the principal cell in following high stimulation frequencies even when quantal output is low because of synaptic depression.

In summary, our data are consistent with a presynaptic locus for synaptic depression induced at $1-10 \mathrm{~Hz}$ stimulation frequencies, with a small contribution from presynaptic mGluR activa-
A
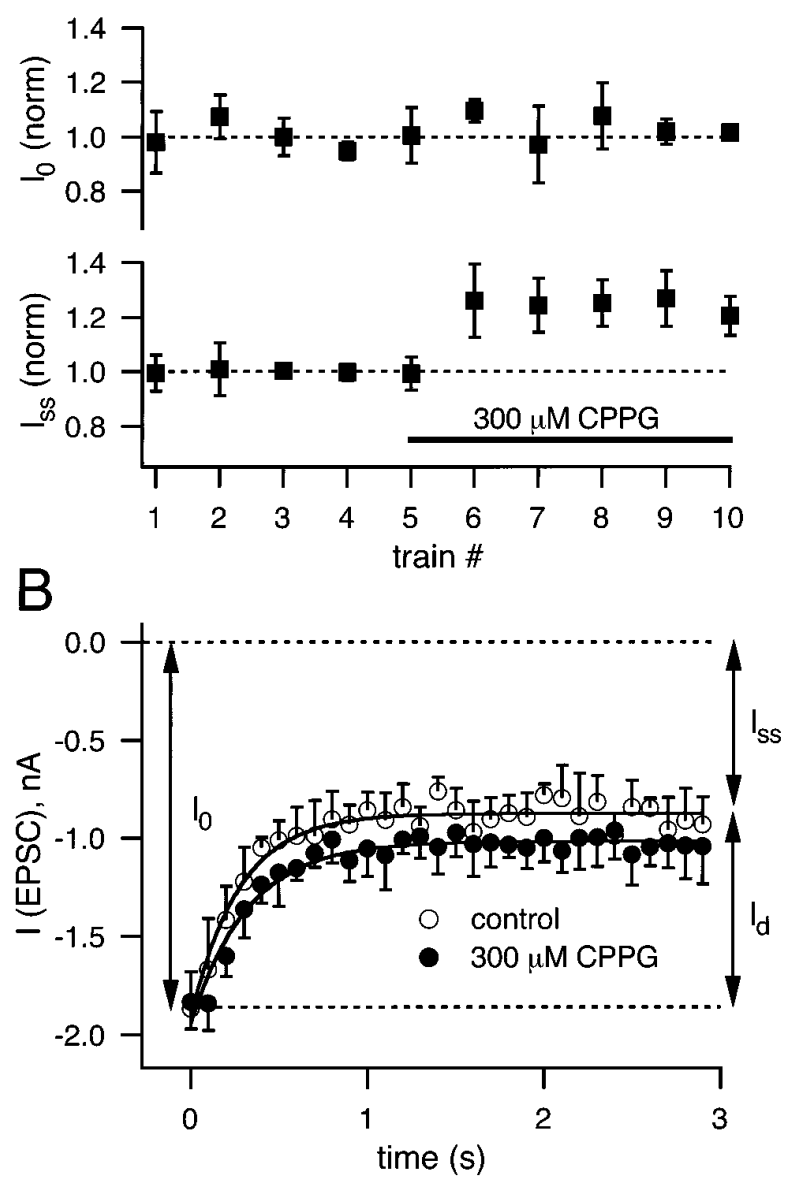

Figure 7. Depression in the presence of CPPG. Trains of 30 stimuli at 5 or $10 \mathrm{~Hz}$ were applied at intervals of $\approx 45 \mathrm{sec}$. After four to five examples of depression in control conditions were obtained, $300 \mu \mathrm{M}$ CPPG was perfused into the slice. $A, I_{0}$ and $I_{\mathrm{ss}}$ for each train were normalized to the corresponding average values of the control group and plotted as a function of the number of trains. Note that, after $300 \mu \mathrm{M}$ CPPG was applied (indicated by the solid bar), $I_{\mathrm{ss}}$ was increased to 1.25 -fold over control, whereas $I_{0}$ was unaffected $(n=4$ cells $) . B$. For a single cell the average depression under control conditions $(n=4$ trains; open symbols $)$ is superimposed on the average depression in the presence of $300 \mu \mathrm{M}$ CPPG $\left(n=4\right.$ trains; closed symbols). Note that $I_{0}$ is unchanged, whereas the decrement in EPSC amplitude induced by depression $\left(I_{\mathrm{d}}\right)$ is slightly reduced by $300 \mu \mathrm{M}$ CPPG.

tion. Because the $[\mathrm{Ca}]_{\mathrm{i}}$ transients in the calyx should not summate significantly at these frequencies (Helmchen et al., 1997), presynaptic calcium current inactivation is an unlikely possibility as a mechanism for depression. We thus suggest that vesicle pool depletion may be the main mechanism inducing depression at these lower frequencies. The calyx of Held synapse, stimulated at 1-10 Hz, thus may become an excellent model system to study synaptic vesicle recruitment at conventional active zones that have been depleted by depression.

\section{REFERENCES}

Abbott LF, Varela JA, Sen K, Nelson SB (1997) Synaptic depression and cortical gain control. Science 275:220-224.

Asztely F, Erdemil G, Kullmann DM (1997) Extrasynaptic glutamate spillover in the hippocampus: dependence on temperature and the role of active glutamate uptake. Neuron 18:281-293.

Atluri PP, Regehr WG (1996) Determinants of the time course of facil- 
itation at the granule cell to Purkinje cell synapse. J Neurosci 16:5661-5671.

Atwood HL, Cooper RL, Wojtowicz JM (1994) Nonuniformity and plasticity of quantal release at crustacean motor nerve terminals. In: Advances in second messenger and phosphoprotein research, Vol 29 (Stjarne L, Greengard P, Grillner S, Hökfelt T, Ottoson D, eds), pp 363-382. New York: Raven.

Barnes-Davies M, Forsythe ID (1995) Pre- and post-synaptic glutamate receptors at a giant excitatory synapse in rat auditory brainstem slices. J Physiol (Lond) 488:387-406.

Baskys A, Malenka RC (1991) Agonists at metabotropic glutamate receptors presynaptically inhibit EPSCs in neonatal rat hippocampus. J Physiol (Lond) 444:687-701.

Bekkers JM, Stevens CF (1989) NMDA and non-NMDA receptors are co-localized at individual excitatory synapses in cultured rat hippocampus. Nature 341:230-233.

Benveniste M, Clements J, Vyklicky L, Mayer ML (1990) A kinetic analysis of the modulation of $N$-methyl-D-aspartic acid receptors by glycine in mouse cultured hippocampal neurones. J Physiol (Lond) 428:333-357.

Betz WJ (1970) Depression of transmitter release at the neuromuscular junction of the frog. J Physiol (Lond) 206:629-644.

Bolshakov VY, Siegelbaum SA (1994) Postsynaptic induction and presynaptic expression of hippocampal long-term depression. Science 264:1148-1152.

Borst JGG, Sakmann B (1996) Calcium influx and transmitter release in a fast CNS synapse. Nature 383:431-434.

Borst JGG, Helmchen F, Sakmann B (1995) Pre- and postsynaptic whole-cell recordings in the medial nucleus of the trapezoid body of the rat. J Physiol (Lond) 489:825-840.

Breakwell NA, Huang L-Q, Rowan MJ, Anwyl R (1997) DCG-IV inhibits synaptic transmission by activation of NMDA receptors in area CA1 of rat hippocampus. Eur J Pharmacol 322:173-178.

Brew H, Forsythe ID (1995) Two voltage-dependent $\mathrm{K}^{+}$conductances with complementary functions in postsynaptic integration at a central auditory synapse. J Neurosci 15:8011-8022.

Burke JP, Hablitz JJ (1994) Presynaptic depression of synaptic transmission mediated by activation of metabotropic glutamate receptors in rat neocortex. J Neurosci 14:5120-5130.

Charlton MP, Smith SJ, Zucker RS (1982) Role of presynaptic calcium ions and channels in synaptic facilitation and depression at the squid giant synapse. J Physiol (Lond) 323:173-193.

Colquhoun D, Jonas P, Sakmann B (1992) Action of brief pulses of glutamate on AMPA/kainate receptors in patches from different neurons of rat hippocampal slices. J Physiol (Lond) 458:261-287.

Debanne D, Guérineau NC, Gähwiler BH, Thompson SM (1996) Paired-pulse facilitation and depression at unitary synapses in rat hippocampus_-quantal fluctuation affects subsequent release. J Physiol (Lond) 491:163-176.

Forsythe ID, Barnes-Davies M (1993) The binaural auditory pathway: excitatory amino acid receptors mediate dual time course excitatory postsynaptic currents in the rat medial nucleus of the trapezoid body. Proc R Soc Lond [Biol] 251:151-157.

Forsythe ID, Clements JD (1990) Glutamate autoreceptors depress excitatory monosynaptic transmission between mouse hippocampal neurones. J Physiol (Lond) 429:1-16.

Forsythe ID, Westbrook GI (1988) Slow excitatory postsynaptic currents mediated by $N$-methyl-D-aspartate receptors on cultured mouse central neurones. J Physiol (Lond) 396:515-533.

Geiger JRP, Melcher T, Koh D-S, Sakmann B, Seeburg PH, Jonas P Monyer H (1995) Relative abundance of subunit mRNAs determines gating and $\mathrm{Ca}^{2+}$ permeability of AMPA receptors in principal neurons and interneurons in rat CNS. Neuron 15:193-204.

Glaum SR, Miller RJ (1993) Metabotropic glutamate receptors depress afferent excitatory transmission in the rat nucleus tractus solitarii. J Neurophysiol 70:2669-2672.

Helmchen F, Borst JGG, Sakmann B (1997) Calcium dynamics associated with a single action potential in a CNS presynaptic terminal. Biophys J 72:1458-1471.

Hessler NA, Shirke AM, Malinow R (1993) The probability of transmitter release at a mammalian central synapse. Nature 366:569-572.

Hestrin S, Sah P, Nicoll RA (1990) Mechanisms generating the time course of dual component excitatory synaptic currents recorded in hippocampal slices. Neuron 5:247-253.
Hsu S-F, Augustine GJ, Jackson MB (1996) Adaptation of $\mathrm{Ca}^{2+}$ triggered exocytosis in presynaptic terminals. Neuron 17:501-512.

Isaacson JS, Walmsley B (1995) Receptors underlying excitatory synaptic transmission in slices of the rat anteroventral cochlear nucleus. J Neurophysiol 73:964-973.

Jane DE, Thomas NK, Tse H-W, Watkins JC (1996) Potent antagonists at the L-AP4 and $(1 S, 3 S)$-ACPD-sensitive presynaptic metabotropic glutamate receptors in the neonatal rat spinal cord. Neuropharmacology 35:1029-1035.

Johnson JW, Ascher P (1987) Glycine potentiates the NMDA response in cultured mouse brain neurones. Nature 325:529-531.

Jones KA, Baughman RW (1991) Both NMDA and non-NMDA subtypes of glutamate receptors are concentrated at synapses on cerebral cortical neurones in culture. Neuron 7:593-603.

Kobayashi K, Manabe T, Takahashi T (1996) Presynaptic long-term depression at the hippocampal mossy fiber-CA3 synapse. Science 273:648-650.

Krieger P, El Manira A, Grillner S (1996) Activation of pharmacologically distinct metabotropic glutamate receptors depresses reticulospinal-evoked monosynaptic EPSPs in the lamprey spinal cord. J Neurophysiol 76:3834-3841.

Kusano K, Landau EM (1975) Depression and recovery of transmission at the squid giant synapse. J Physiol (Lond) 245:13-32.

Legendre P, Rosenmund C, Westbrook GL (1993) Inactivation of NMDA channels in cultured hippocampal neurons by intracellular calcium. J Neurosci 13:674-684.

Lester RAJ, Clements JD, Westbrook GL, Jahr CE (1990) Channel kinetics determine the time course of NMDA receptor-mediated synaptic currents. Nature 346:565-567.

Liu G, Tsien RW (1995) Properties of synaptic transmission at single hippocampal synaptic boutons. Nature 375:404-408.

Lohmann C, Friauf E (1996) Distribution of the calcium-binding proteins parvalbumin and calretinin in the auditory brainstem of adult and developing rats. J Comp Neurol 367:90-109.

Lomeli H, Mosbacher J, Melcher T, Höger T, Geiger JRP, Kuner T, Monyer H, Higuchi M, Bach A, Seeburg PH (1994) Control of kinetic properties of AMPA receptor channels by nuclear RNA editing. Science 266:1709-1713.

Macek TA, Winder DG, Gereau RW, Ladd CO, Conn PJ (1996) Differential involvement of group II and group III mGluRs as autoreceptors at lateral and medial perforant path synapses. J Neurophysiol 76:3798-3806.

Magleby KL (1987) Short-term changes in synaptic efficacy. In: Synaptic function (Edelman GM, Gall WE, Cowan WM, eds), pp 21-56. New York: Wiley.

Magleby KL, Pallotta BS (1981) A study of desensitization of acetylcholine receptors using release at the frog neuromuscular junction. J Physiol (Lond) 316:225-250.

Maki R, Cummings DD, Dichter MA (1995) Frequency-dependent depression of excitatory synaptic transmission is independent of activation of MCPG-sensitive presynaptic metabotropic glutamate receptors in cultured hippocampal neurons. J Neurophysiol 74:1671-1674.

Murthy VN, Sejnowski TJ, Stevens CF (1997) Heterogeneous release properties of visualized individual hippocampal synapses. Neuron 18:599-612.

Nakanishi S (1994) Metabotropic glutamate receptors: synaptic transmission, modulation, and plasticity. Neuron 13:1031-1037.

Otis TS, Zhang S, Trussell LO (1996) Direct measurement of AMPA receptor desensitization induced by glutamatergic synaptic transmission. J Neurosci 16:7496-7504.

Perkel DJ, Nicoll RA (1993) Evidence for all-or-none regulation of neurotransmitter release: implications for long-term potentiation. J Physiol (Lond) 471:481-500.

Redman RS, Silinsky EM (1994) ATP released together with acetylcholine as the mediator of neuromuscular depression at the frog motor nerve endings. J Physiol (Lond) 477:117-127.

Rosenmund C, Stevens CF (1996) Definition of the readily releasable pool of vesicles at hippocampal synapses. Neuron 16:1197-1207.

Rosenmund C, Clements JD, Westbrook GL (1993) Nonuniform probability of glutamate release at a hippocampal synapse. Science 262:754-757.

Saugstad JA, Segerson TP, Westbrook GL (1995) Modulation of ion channels and synaptic transmission by metabotropic glutamate receptors. In: Excitatory amino acids and synaptic transmission (Wheal $\mathrm{H}$, Thomson A, eds), pp 77-88. New York: Academic. 
Scanziani M, Salin PA, Vogt KE, Malenka RC, Nicoll RA (1997) Usedependent increases in glutamate concentration activate presynaptic metabotropic glutamate receptors. Nature 385:630-634.

Schneggenburger R, Zhou Z, Konnerth A, Neher E (1993) Fractional contribution of calcium to the cation current through glutamate receptor channels. Neuron 11:133-143.

Smith PH, Joris PX, Carney LH, Yin TC (1991) Projections of physiologically characterized globular bushy cell axons from the cochlear nucleus of the cat. J Comp Neurol 304:387-407.

Stevens CF, Tsujimoto T (1995) Estimate for the pool size of releasable quanta at a single central synapse and for the time required to refill the pool. Proc Natl Acad Sci USA 92:846-849.

Stuart GJ, Dodt H-U, Sakmann B (1993) Patch-clamp recordings from the soma and dendrites of neurons in brain slices using infrared video microscopy. Pflügers Arch 423:511-518.

Swandulla D, Hans M, Zipser K, Augustine GJ (1991) Role of residual calcium in synaptic depression and posttetanic potentiation: fast and slow calcium signaling in nerve terminals. Neuron 7:915-926.

Takahashi T, Forsythe ID, Tsujimoto T, Barnes-Davies M, Onodera K (1996) Presynaptic calcium current modulation by a metabotropic glutamate receptor. Science 274:594-597.

Tanabe Y, Nomura A, Masu M, Shigemoto R, Mizuno N, Nakanishi S (1993) Signal transduction, pharmacological properties, and expression patterns of two rat metabotropic glutamate receptors, mGluR3 and mGluR4. J Neurosci 13:1372-1378.

Thies RE (1965) Neuromuscular depression and the apparent depletion of transmitter in mammalian muscle. J Neurophysiol 28:427-442.

Thomson AM, Deuchars J, West DC (1993) Large, deep layer pyramidpyramid single axon EPSPs in slices of rat motor cortex display paired pulse and frequency-dependent depression, mediated presynaptically and self-facilitation, mediated postsynaptically. J Neurophysiol 70:2354-2369.

Tong G, Jahr CE (1994a) Multivesicular release from excitatory synapses of cultured hippocampal neurons. Neuron 12:51-59.

Tong G, Jahr CE (1994b) Block of glutamate transporters potentiates postsynaptic excitation. Neuron 13:1195-1203.

Trussell LO, Zhang S, Raman IM (1993) Desensitization of AMPA receptors upon multiquantal neurotransmitter release. Neuron 10:1185-1196.

Tsodyks MV, Markram H (1997) The neural code between neocortical pyramidal neurons depends on neurotransmitter release probability. Proc Natl Acad Sci USA 94:719-723.

von Gersdorff H, Matthews G (1996) Calcium-dependent inactivation of the calcium current in synaptic terminals of retinal bipolar neurons. J Neurosci 15:115-122.

von Gersdorff H, Matthews G (1997) Depletion and replenishment of vesicle pools at a ribbon-type synaptic terminal. J Neurosci 17:1919-1927.

Wu SH, Kelly JB (1993) Response of neurones in the lateral superior olive and medial nucleus of the trapezoid body to repetitive stimulation: intracellular and extracellular recordings from the mouse brain slice. Hear Res 68:189-201.

Wu L-G, Saggau P (1997) Presynaptic inhibition of elicited neurotransmitter release. Trends Neurosci 20:204-223.

Yawo H, Momiyama A (1993) Re-evaluation of calcium currents in preand postsynaptic neurones of the chick ciliary ganglion. J Physiol (Lond) 460:153-172.

Yokoi M, Kobayashi K, Manabe T, Takahashi T, Sakaguchi I, Katsuura G, Shigemoto R, Ohishi H, Nomura S, Nakamura K, Nakao K, Katsuki M, Nakanishi S (1996) Impairment of hippocampal mossy fiber LTD in mice lacking mGluR2. Science 273:645-647.

Zhang S, Trussell LO (1994) Voltage-clamp analysis of excitatory synaptic transmission in the avian nucleus magnocellularis. J Physiol (Lond) 480:123-136.

Zhang Z-w, Coggan JS, Berg DK (1996) Synaptic currents generated by neuronal acetylcholine receptors sensitive to $\alpha$-bungarotoxin. Neuron 17:1231-1240.

Zorumski CF, Mennerick S, Que J (1996) Modulation of excitatory synaptic transmission by low concentrations of glutamate in cultured rat hippocampal neurones. J Physiol (Lond) 494:465-477.

Zucker RS (1989) Short-term synaptic plasticity. Annu Rev Neurosci 12:13-31. 